2019 p.

Вип. 20

Машинобудування і зварювальне виробництво

УДК 621.9.048.6-033.7

Бурлаков В. I.

\title{
ВПЛИВ ВІБРАЦЙНОЇ ОБРОБКИ НА ЗМЕНШЕННЯ ЗАЛИШКОВИХ НАПРУЖЕНЬ У ЗРАЗКАХ 3 НАДТВЕРДОЇ КЕРАМІКИ
}

Досить своєрідні властивості кераміки дають можливість використовувати в якості ріжучої пластини інструменту. Кераміка може застосовуватися і при виготовленні деталей машин, приладів та радіоелектронної апаратури. Через те, щяо кераміка має високу твердість обробка різанням заготовок можлива при використанні итучних алмазів. Удосконалення прийомів обробки надтвердої кераміки пов'язано, пери за все, з вивченням закономірностей досить складного прочесу шліфування.

Важллву роль при визначенні стійкості інструменту грає наявність внутрішніх напружень в матеріалі. Боротьба з ними є важливим завданням дослідників.

Існує деяка різноманітність методів визначення величини залишкових напруг в матеріалах взагалі і надтвердої кераміки зокрема. Одним з таких методів є дифракиійний. Дифракиійні методи широко використовуються у багатьох областях для дослідження фазового складу, структури та аналізу дефектів кристалів. Цей метод заснований на дифракиії різних типів хвиль на решітці кристала. Вибір хвильових пучків обмежується можливістю досягнення довжини хвиль, менших розмірів елементарних осередків кристала $i$ технічною можливістю їх отримання і проведення дифракційного методу. Виходячи з цих факторів, найбільшого поширення в практиці отримали дифракцію на кристалі рентгенівських променів (як характеристичного, так $і$ синхротронного випромінювання), електронів $і$ теплових нейтронів. При ідентифікації речовин істотне саме положення рентгенівських ліній з урахуванням їх деякої інтенсивності.

Рентгенограми матеріалів представляють собою набір ліній різної інтенсивності на плівиі або піків різної висоти на діаграмному папері; становище иих рефлексів визначається міжплощинні відстані або бреггівськими кутами розсіювання. Вивчення дифрактограм дозволить встановити величину залікових напружень у тому чи іншому матеріалі.

Ключові слова: властивості кераміки, дифракційні методи, стійкість інструменту, механічна обробка, рентгенограми матеріалів, якість ріжучого інструменту, дифракції різних типів хвиль.

Постановка проблеми. Актуальним науково-технічним завданням $є$ продовження стійкості інструменту з надтвердої кераміки, що сприяє отриманню прийнятної якості обробленої поверхні і підвищенню продуктивності устаткування.

Аналіз останніх досліджень i публікацій. Дана проблема піднімалася М. А. Штремель [1] Розглядалися процеси деформації і зміцнення металів, сплавів i композиційних матеріалів, який вивчав характеристики міцності різних матеріалів і сплавів, зачіпалася Г. Томасом [2], приділив увагу просвічує електронної мікроскопії матеріалів, Моріс Ф. [3] , вивчав мікроаналіз і растрового електронного мікроскопу.

Мета статті: Показати, що вібраційна обробка може підвищити стійкість інструменту 3 надтвердої кераміки шляхом зменшення залишкових напружень в матеріалі.

Виклад основного матеріалу. Розробка методів вимірювання залишкових напружень в даний час $\epsilon$ нагальною, i $\epsilon$ актуальним завданням. Саме через відсутність зручних $\mathrm{i}$ швидких способів вимірювань, рішення проблеми залишкових напруг відстає від аналогічної - для напружених станів під дією активних навантажень. Однак, в останні десятиліття в результаті зусиль вчених України, США, Німеччини, Англії, Угорщини та інших країн

Режим доступу: http://sap.pstu.edu 


\section{Машинобудуання і зварювальне виробництво}

становище з вимірювальними методами і засобами істотно покращився і почалося активне експериментальне вивчення таких напружених станів [1]. Але багато чого ще не зроблено: для отримання загальних висновків про вплив залишкових напружень на міцність конструкцій належить досліджувати напруги в дуже великому обсязі матеріалів і виробів.

Необхідно атестувати технологічні операції по тому напруженому стану, який вони вносять в готовий виріб, вміти оцінювати значення цього стану і знаходити способи управління технологічними процесами i напруженнями, що викликаються ними для поліпшення якості виробів і надійності їх роботи.

У науковій літературі є багатий науковий досвід, присвячений дослідженням різних напружено-деформованих станів твердих тіл, створених доданими до них навантаженнями, температурними полями, взаємодіями 3 іншими тілами і т.д. [2]. Чим же проблема попередніх напружених станів відрізняється від проблеми звичайних напруг? Чому іiі потрібно виділяти, як особливу? Розробники вміють добре розраховувати конструкцію на міцність.

Однак при розслідуванні причин деяких аварій доводиться стикатися 3 такою ситуацією: при вимірюванні залишкової напруги виявляється, що ці напруги досить великі, а в документах на зруйнований виріб стверджується, що в даному місці напружень немає. Під час технологічних процесів виготовлення у виробі утворились значні попередні напруги, які були непомітними. I подібні ситуації на практиці досить часті. Ясно, що необхідні робочі методи, які дозволяли б визначати такі напруги в тілах після всіх процесів виготовлення, щоб знизити ймовірність аварій [3]. Наявність внутрішньої напруги в пластинах 3 надтвердих матеріалів призводить до зменшення терміну служби пластин і передчасного руйнування. Отже, необхідно позбавлятися від осередків концентрацій внутрішніх напружень за допомогою вібраційної обробки пластин. Зазвичай для визначень мікронапруг II роду застосовується метод зворотної зйомки. При використанні дифрактометра реєструють інтерференційні лінії з максимальним кутом $\theta$. Область когерентного розсіювання (ОКР) - це мінімальний розмір частки речовини, що має правильну кристалічну будову, на якій рентгенівські промені розсіюються когерентно, тобто з постійною різницею фаз. Основною метою діфрактометричного аналізу є:

1. Встановлення величини мікродеформацій.

2. Установлені величини мікронапруг.

3. Встановлення величини блоків мозаїки.

Такими причинами можуть бути: наявність мікронапруг другого роду, зміна блоків мозаїки, або вплив обох факторів одночасно.

Аналізуючи дифрактограми поверхні пластин з надтвердої кераміки робимо висновок про те, що максимальний екстремум, що говорить про наявність внутрішніх напружень знаходиться на пластині без обробки, потім у міру збільшення часу обробки цей екстремум зменшується. Це однозначно говорить про те, що використовуючи вібраційну обробку можна досягти зменшення внутрішньої напруги, що призведе до збільшення терміну служби пластини з надтвердої кераміки. На підставі дифрактограм можна побудувати графік (рис 2) залежності концентрації внутрішніх напружень від часу обробки. 


\section{Машинобудування і зварювальне виробництво}

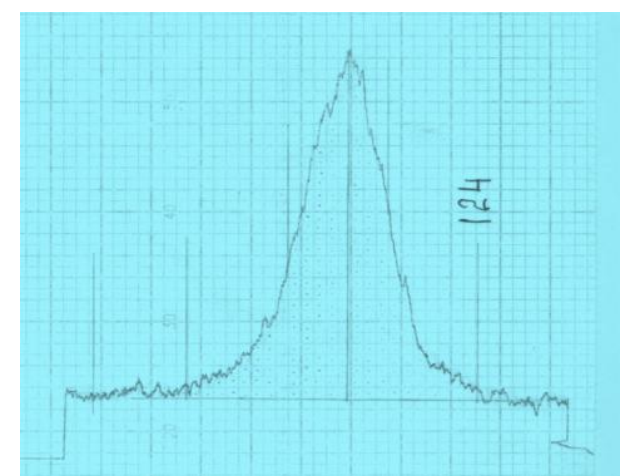

a

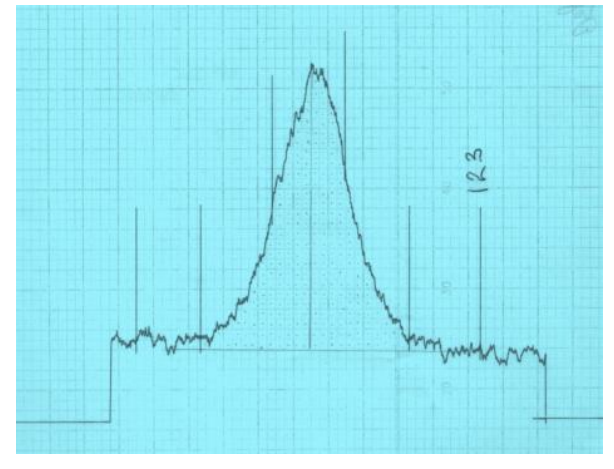

B

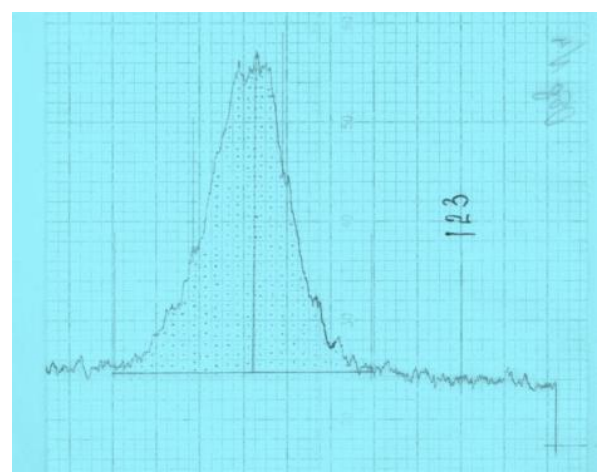

6

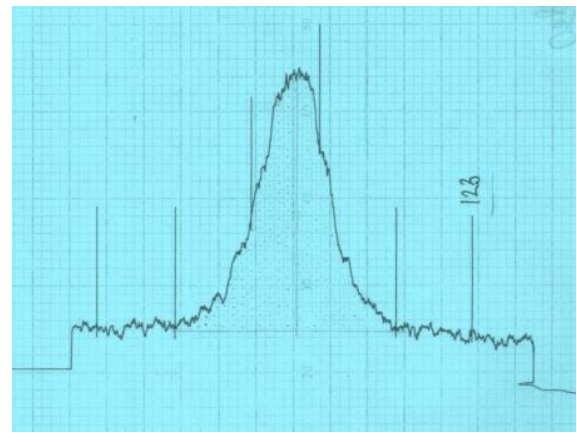

$\Gamma$

Рисунок 1 - Дифрактограми поверхонь при куті відображення 124룽

а - зразок без обробки; б - зразок після 40 хвилин обробки;

в - зразок після 20 хвилин обробки; г - зразок після 30 хвилин обробки

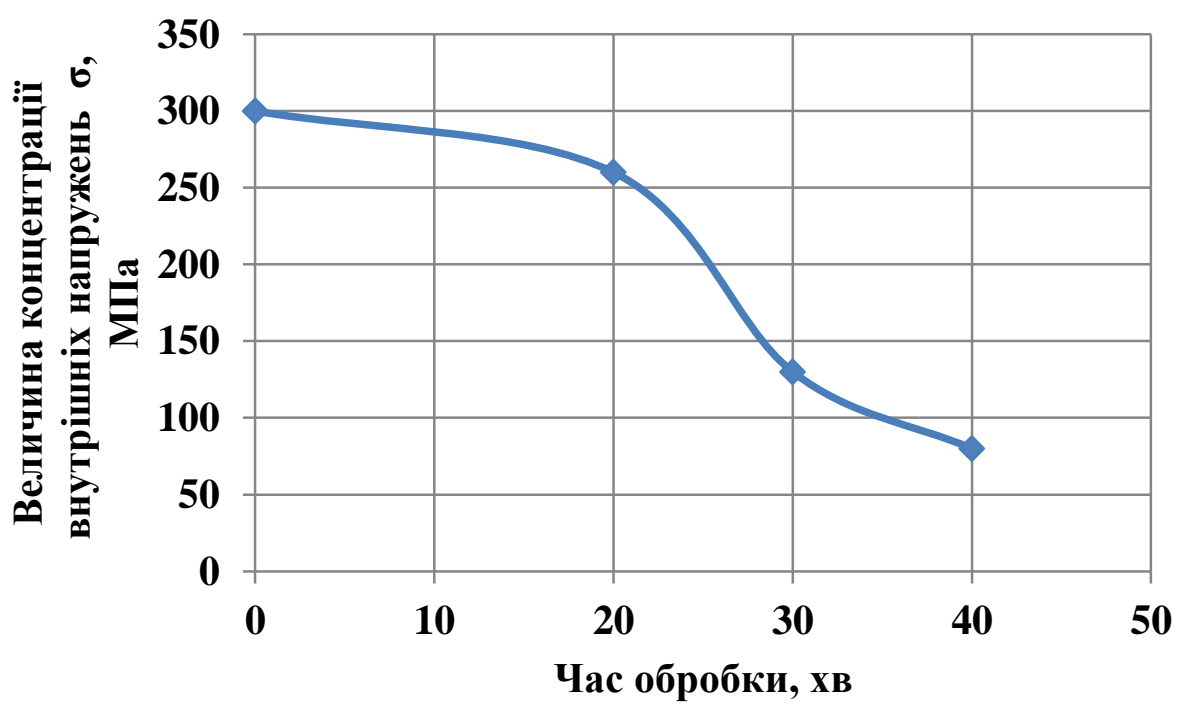

Рисунок 2 - Залежність концентрації внутрішніх напружень від часу обробки 
$2019 \mathrm{p}$.

Вип. 20

\section{Машинобудування і зварювальне виробництво}

Для підтвердження теорії про те, що вібраційна обробка сприяє зниженню внутрішніх напружень, заміри були проведені під різними кутами відображення, а дифрактограми наведені нижче.

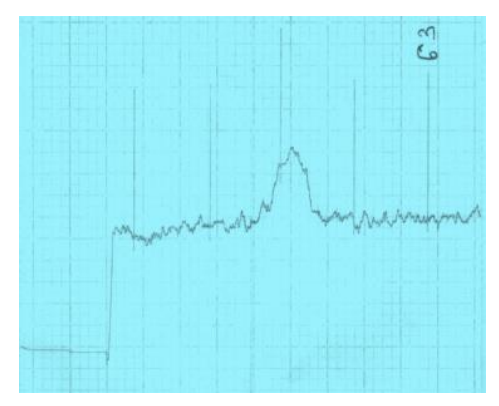

$\mathrm{a}$

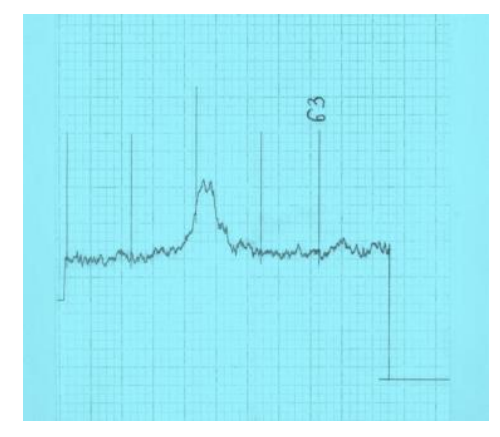

B

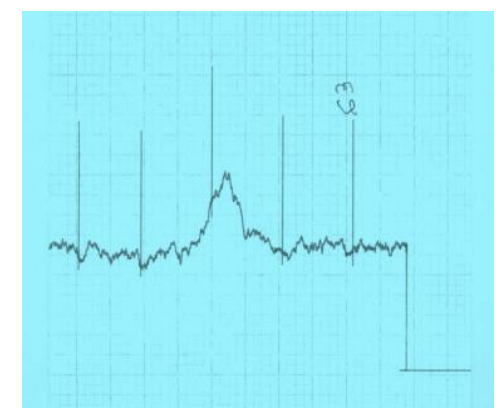

6

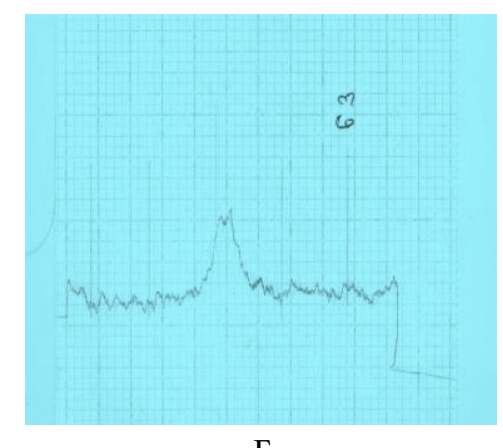

$\Gamma$

Рисунок 3 - Дифрактограми поверхонь при куті відображення $63^{\circ}$ :

а - зразок без обробки; б - зразок після 20хвилин обробки;

в - зразок після 30 хвилин обробки; г - зразок після 40 хвилин обробки

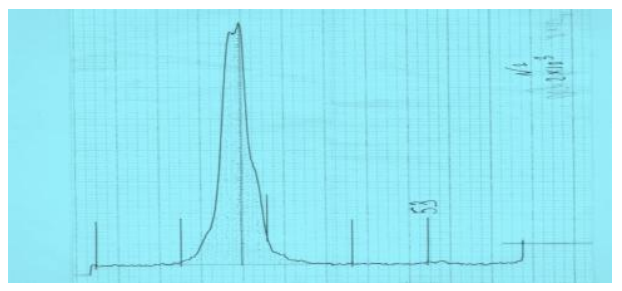

a

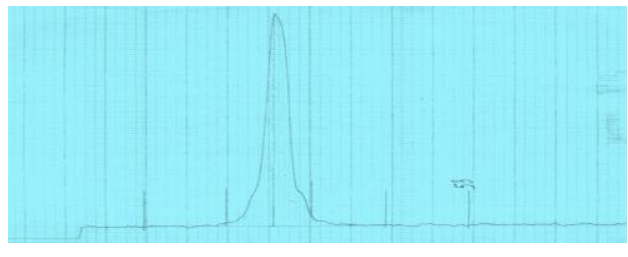

B

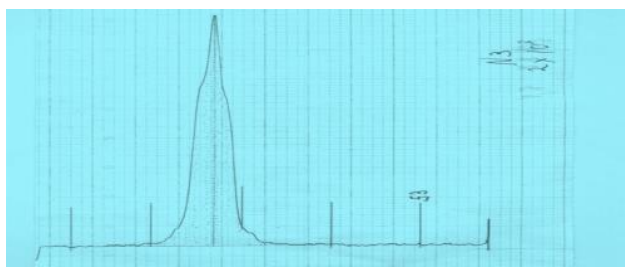

6

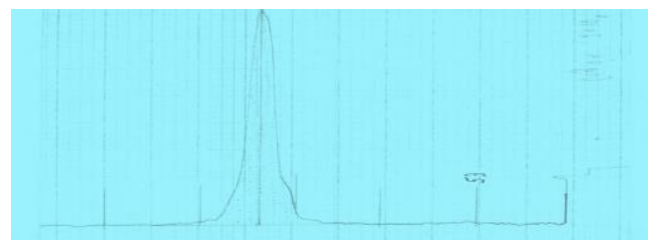

$\Gamma$

Рисунок 4 - Дифрактограми поверхонь при куті відображення 53룽 a - зразок після 20 хвилин обробки б - зразок після 30 хвилин обробки; в - зразок без обробки; г - зразок після 40хвилин обробки

Режим доступу: http://sap.pstu.edu 


\section{Машинобудування і зварювальне виробництво}

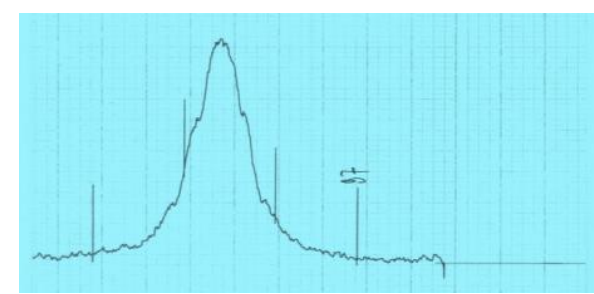

a

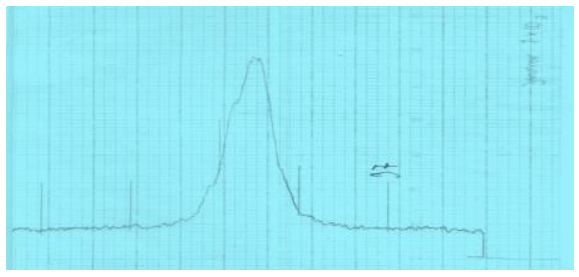

B

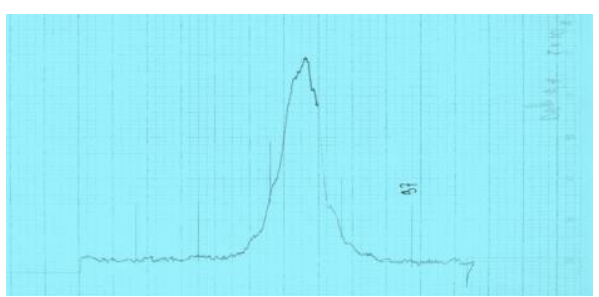

6

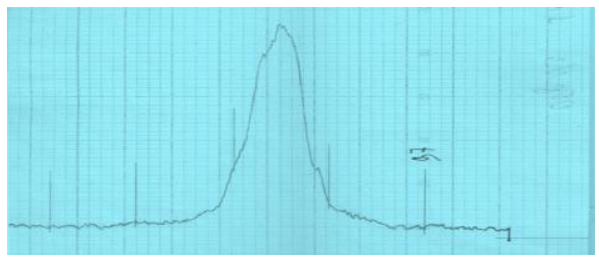

$\Gamma$

Рисунок 5 - Дифрактограми поверхонь при куті відображення $97^{0}$ : a - зразок після 20 хвилин обробки б - зразок після 40 хвилин обробки; в - зразок без обробки; г - зразок після 30 хвилин обробки

Як видно з рисунків 3-5, картина розподілу концентрації внутрішніх напружень до i після обробки, яка була виміряна під різними кутами відображень носить практично постійний характер, що саме по собі підтверджує справедливість проведених експериментів. Змінність піків на дифрактограмах підтверджує версію про те, що вібраційна обробка сприяє зняттю залишкових напружень в надтвердой кераміці. Стрімкість піків помітно спадає. Це пояснюється тим, що процес релаксації пройшов дуже успішно.

Залишкові мікро- і макронапруження, що виникли в матеріалі не залишаються постійними, а змінюються 3 плином часу. Релаксація макронапружень може супроводжуватися загальною деформацією деталі, іноді настільки значної, що вона спостерігається візуально або викликає руйнування (поява тріщини). До того ж, наявність якоїсь частини напружень в кераміці сприятиме зняттю матеріалу з поверхні при обробці. Але мета наших експериментів досягнута і залишкові напруження зменшилися саме за допомогою вібраційної обробки.

\section{ВИСНОВКИ}

1. Мікронапруження, які урівноважують в обсягах окремих кристалів і блоків, не можна визначити механічними методами. Але вони легко визначаються по розширенню інтерференційних ліній на рентгенограмі.

2. Вібраційна обробка сприяє зниженню концентрації внутрішніх напружень приблизно на $30 \%$.

3. Вібраційна обробка знижує величину мікродеформацій приблизно на $5 \%$.

4. У міру збільшення часу обробки екстремум, що говорить про величину внутрішніх напружень, зменшується. 
$2019 \mathrm{p}$.

Вип. 20

\section{Машинобудування і зварювальне виробництво}

Перелік використаних джерел:

1. Штремель, М. А. Прочность сплавов. Ч. І. Дефекты решётки / М. А. Штремель. М. : МИСИС, 1999. - 384 с.

2. Томас, Г. Просвечивающая электронная микроскопия материалов / Г. Томас, М. Дж. Гориндж. - М. : Мир, 1983. - 320 с.

3. Морис, $\Phi$. Микроанализ и растровая электронная микроскопия / Ф. Морис, Л. Мени, Р. Тиксье.- М. : Металлургия, 1985. - 407 с.

Бурлаков В. И.

\section{ВЛИЯНИЕ ВИБРАЦИОННОГО ВОЗДЕЙСТВИЯ НА УМЕНЫШЕНИЕ ОСТАТОЧНЫХ НАПРЯЖЕНИЙ В ОБРАЗЦАХ ИЗ СВЕРХТВЕРДОЙ КЕРАМИКИ}

Достаточно своеобразные свойства керамики дают возможность использовать в качестве режущей пластины инструмента. Керамика может применятся, и при изготовлении деталей машин, приборов и радиоэлектронной аппаратуры. Из-за того, что керамика обладает высокой твердостью обработка резанием заготовок возможна при использовании искусственных алмазов. Совершенствование приемов обработки сверхтвердой керамики связано, прежде всего, с изучением закономерностей достаточно сложного прочесса шлифования.

Немаловажную роль при определении стойкости инструмента играет наличие внутренних напряжений в материале. Борьба с ними является важной задачей исследователей. Существует некоторое разнообразие методов определения величины остаточных напряжений в материалах вообще и сверхтвердой кералике в частности. Одним из таких методов является дифракционный. Дифракционные методы широко используются во многих областях для исследования фазового состава, структуры и анализа дефектов кристаллов. Этот метод основан на дифракиии различных типов волн на решетке кристалла. Выбор волновых пучков ограничивается возможностью достижения длин волн, меньших размеров элементарных ячеек кристалла и технической возможностью их получения и проведения дифракционного метода.

Исходя из этих факторов, наибольшее распространение в практике получили дифракиия на кристалле рентгеновских лучей (как характеристического, так и синхротронного излучения), электронов и тепловых нейтронов. При идентификачии веществ существенно именно положение рентгеновских линий с учетом их некоторой интенсивности.

Рентгенограммы материалов представляют собой набор линий различной интенсивности на пленке или пиков различной высоты на диаграммной бумаге; положение этих рефлексов определяется межплоскостными расстояниями или брэгговскими углами рассеяния.

Положение рентгеновских линий фиксировано и характерно только этому соединению. Интенсивность линий может меняться в зависимости от способа получения образиа и условий съемки.

Ключевые слова: свойства керамики, дифракционные методы, стойкость инструмента, механическая обработка, рентгенограммы материалов, качество режущего инструмента, дифракции различных типов волн. 
Машинобудування і зварювальне виробництво

Burlakov V.I.

\section{THE INFLUENCE OF VIRTUAL PROCESSING ON REDUCTION OF CURRENT STRESS IN EXAMINATIONS WITH PERFECT CERAMIC}

Unique properties of ceramics allow to utillize it in the different areas of technique, including as a toolpiece and details of machines, devices and radio electronic apparatus. From high hardness of material tooling of purveyances is possible only with the use of synthetic diamonds. Perfection of methods of treatment of ceramics is related to the study of conformities to the law of difficult multivariable process of polishing.

Diffraction methods are widely utillized in chemistry, physics and materials science for research of phase composition, structure and analysis of imperfections of crystals. They are based on diffraction of different types of waves on the periodic grate of crystal. The choice of nature of wave bunches is limited to possibility of achievement of lengths of waves, less characteristic sizes of elementary cells of crystal and by economic feasibility of their receipt and leadthrough of diffraction experiment. Coming from these factors, most distribution in practice of researches was got diffraction on the crystal of $x$-rays (both characteristic and synchrotron radiation), electrons and thermal-neutron. During authentication of matters most substantially exactly position of x-ray photography lines taking into account their relative intensity.

Sciagrams of materials are a set of lines of different intensity on a film or peaks is determined interplanar distances or braggish corners of dispersion.

Not unimportant role at determination of firmness of instrument can play the presence of internal tensions. A fight against them is the important task of researchers.

Position of x-ray photography lines is fixed and characteristically only to this connection. Intensity of lines can change depending on the method of receipt of standard and terms of survey.

Keywords: properties of ceramics, diffraction methods, tool resistance, machining, X-ray diffraction patterns of materials, quality of cutting tools, diffraction of various types of waves

Рецензент: д-р техн. наук, проф. ДВНЗ «ПДТУ» Самотугін С. С.

Стаття надійшла 28.02.2019 p. 


\section{ВЛИЯНИЕ СПОСОБА НАПЛАВКИ НА ДОЛЮ УЧАСТИЯ ОСНОВНОГО МЕТАЛЛА В НАПЛАВЛЕННОМ}

B статье приведень способы широкослойной механизированной наплавки с использованием различных электродных материалов, а также влияние технологических факторов на долю участия основного металла в наплавленном. Установлено, что использование широкослойной механизированной электродуговой наплавки порошковыми лентами позволяет получить заданный химический состав и необходимую ширину наплавленного слоя с обеспечением минимальной доли участия основного металла в наплавленном.

Ключевые слова: широкослойная наплавка, наплавленный слой, химический состав, износостойкость, порошковая лента.

Вступление. Для восстановления или нанесения требуемого износостойкого сплава на поверхности деталей машин, работающих в условиях интенсивного изнашивания, используют различные способы наплавки. В большинстве случаев наплавку выполняют отдельными валиками с соответствующими перекрытиями, что приводит к неоднородности формирования износостойкой фазы и, как следствие, неоднородности свойств в наплавленном слое [1-3].

Постановка проблемы. Большую роль в получении и требуемого химического состава, формировании структуры для обеспечения необходимых свойств наплавленного металла, играет доля участия основного металла в наплавленном, которая может изменяться в широких пределах. Известны разные факторы, оказывающие влияние на проплавление основного металла и его участие а формировании наплавленного слоя, такие как: сила сварочного тока, скорость наплавки, вид и размеры электродного материала.

Основной материал исследования. Был проведен анализ влияния способа наплавки на долю участия основного металла в наплавленном. Общий вид сечения наплавленного слоя показан на рис. 1 [4].

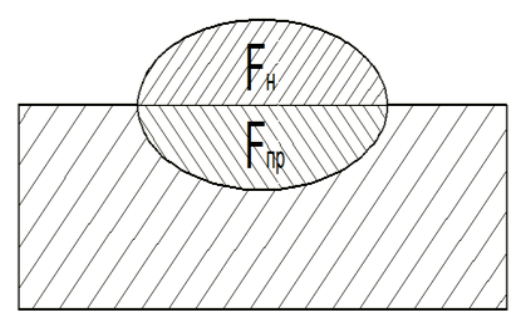

Рисунок 1 - Схема расчета доли участия основного металла в наплавленном

Доля основного металла в наплавленном, определяется отношением площади проплавления основного металла к общей площади шва:

$$
m=\frac{F_{n p}}{F_{n p}+F_{H}} \cdot 100 \%
$$

Режим доступу: http://sap.pstu.edu 